\title{
PERSEPSI PEGIAT J ENDER TERHADAP KONSEP PASAL 31 AYAT (3) UNDANG-UNDANG PERKAWINAN TENTANG STATUS KEPALA KELUARGA*
}

\author{
Tri Lisiani Prihatinah \\ Fakultas Hukum UNSOED Purwokerto \\ E-mail: tlisiani@yahoo.com.
}

\begin{abstract}
Some of gender activists assume that status of husband as a head of household is discriminating wife. Therefore, they propose a gender equality model which gives the same status to both husband and wife as a head of household altogether. By using sociological method and feminist legal analysis, it is resulted that most gender activists who become the source of information in this research do not agree with the proposed model of gender equality because they do believe its legal consequence will burden more to the wife. However, they agree that women develop their economic ability to ear money. These gender activists do not want to amend Article 31 (3) Law Number 1 Year 1974. They understand this article as a reflection of substantive equality which recognizes husband as a head of household's status is parallel with the burden of the responsibility.
\end{abstract}

Key words: gender equality, head household

\begin{abstract}
Abstrak
Status suami sebagai kepala keluarga dalam hukum perkawinan yang berlaku selama ini dianggap sebagian pegiat jender sebagai hukum yang mendiskriminasikan perempuan. Sehingga mereka mengajukan model kesetaraan jender dengan suami dan istri bersama-sama mempunyai status sebagai kepala keluarga. Dengan menggunakan metode yuridis-sosiologis dan analisis hukum feminis, ternyata diperoleh hasil bahwa hampir semua pegiat jender yang menjadi sumber informasi tidak menyetujui terhadap model kesetaraan tersebut, karena konsekuensi hukumnya akan semakin membebani istri. Tetapi mereka setuju istri mengembangkan kemampuan ekonomi dalam mencari nafkah. Pegiat jender ini tidak menghendaki dilakukannya amandemen terhadap Pasal 31(3) UU No. 1 Tahun 1974, karena pasal ini sebagai refleksi dari kesetaraan substantif yang mengakui status suami sebagai kepala keluarga paralel dengan besarnya kewajiban yang harus ditanggungnya.
\end{abstract}

Kata kunci: model, kesetaraan jender, kepala keluarga

\section{Pendahuluan}

Sejak tahun 1974 semua rakyat Indonesia tunduk pada hukum perkawinan nasional yang sama yaitu UU Nomor 1 tahun 1974. Dalam Pasal 31 ayat 3 UU Perkawinan tersebut dinyatakan bahwa suami berkedudukan sebagai kepala rumah tangga dan istri sebagai ibu rumah tangga. Status suami sebagai kepala runah tangga dalam hukum perkawinan selama ini dianggap oleh sebagian pegiat jender sebagai hukum yang mendiskriminasikan perempuan dimana perempuan tidak hanya menanggung beban yang lebih berat dibanding laki-laki,

* Artikel ini merupakan artikel hasil penelitian Hibah Bersaing dengan sumber dana dari Dikti 2009. tetapi juga hak-haknya sebagai manusia tidak dapat sepenuhnya dipenuhi. ${ }^{1}$ Dengan pemahaman seperti itu, ada pihak yang mengajukan rancangan perubahan status kepala keluarga yang berkesetaraan jender dimana laki-laki dan perempuan bersama-sama sebagai kepala keluarga. ${ }^{2}$ Tetapi kenyataannya tidak semua masyarakat menyetujui adanya konsep kesetaraan jender tersebut, meskipun kebijakan berkesetaraan jender ini sudah menjadi komit-

Endang Sumiarni, 2005, Kajian Hukum Perkawinan Yang Berkesetaraan J ender, Yogyakarta: Wonderful Publishing Company, hlm.17.

2 LBH-APIK/ Lembaga Bantuan Hukum-APIK, 2005, Usulan Amandemen UU Perkawinan Nomor 1 tahun 1974 berikut argumen-argumennya. 
men Pemerintah Indonesia untuk mewujudkannya.

Ketidaksetujuan masyarakat terhadap perubahan status perempuan dan laki-laki bersama-sama sebagai kepala keluarga disebabkan oleh berbagai alasan. Pertama, keberagaman pendapat terhadap konsep suami-istri sebagai kepala keluarga bertentangan dengan nilai-nilai agama yang dianut sebagian besar masyarakat Indonesia. Kedua, ketidakpahaman dan ketidaktahuan masyarakat terhadap konsep kesetaraan jender yang dikhawatirkan dapat menggoncang keutuhan keluarga karena menurut pendapat ini konsep kesetaraan jender mengajarkan perempuan untuk melawan laki-laki. Ketiga, stigmatisasi bahwa status kepala keluarga berkesetaraan jender akan menyebabkan diskriminasi terhadap laki-laki karena hukum keluarga berkesetaraan jender ini akan terlalu banyak memberikan tambahan hak kepada perempuan. Hal ini didasarkan pada pemikiran bahwa hukum perkawinan yang ada sekarang ini sudah memberikan hak dan kewajiban yang adil kepada laki-laki dan perempuan. Keempat, stigma bahwa kesetaraan jender berasal dari konsep barat yang lebih mendorong terjadinya gaya hidup negatif seperti maraknya pergaulan bebas, meningkatnya jumlah perceraian dan lain-lain. Selain itu pendekatan materialistis dan sekuler untuk tercapainya kesetaraan jender yang sudah dilakukan selama ini dianggap secara frontal menyerang nilai-nilai agama dan institusi-institusi sosial yang sudah mapan memperparah stigma ini.

Wacana untuk melakukan perubahan relasi suami istri dalam sistem hukum keluarga ini merupakan hal serius karena akan membawa konsekuensi hukum pada pihak-pihak yang bersangkutan diantaranya adalah penambahan tanggungj awab hukum. Apalagi hubungan suami istri dalam UU Perkawinan Nomor 1 Tahun 1974 tersebut telah diatur secara tertutup dan ber- sifat limitatif serta tidak dapat disimpangi. ${ }^{3}$

Berdasarkan hal tersebut di atas, maka perlu diketahui bagaimana sebenarnya persepsi masyarakat terhadap konsep kesetaraan jender itu sendiri khususnya dalam relasi jender dalam keluarga. Pemahaman terhadap hal ini adalah sangat penting karena merupakan suatu keharusan agar tercapai tujuan yang sudah ditetapkan yaitu tercapainya kehidupan berkeluarga khususnya dapat terlindunginya perempuan yang bisanya merupakan korban kekerasan dalam rumah tangga, meski tidak menutup kemungkinan laki-laki juga merupakan korban kekerasan serupa.

\section{Perumusan Masalah}

Ada beberapa masalah yang hendak dibahas pada tulisan ini. Pertama, bagaimana persepsi terhadap konsep kesetaraan dan kepemimpinan?; Kedua, bagaimana persepsi terhadap hak dan kewajiban suami istri?; Ketiga, bagaiman persepsi terhadap hak dan kewajiban sebagai orang tua?; Keempat, bagaimana persepsi terhadap hak dan kewajiban terhadap harta?; dan Kelima, bagaimana persepsi terhadap pewarisan?

\section{Metode Penelitian}

Penelitian ini menggunakan metode yuridis-sosiologis. Dalam penelitian ini, peneliti menggali persepsi mereka terhadap status kepala keluarga. Informasi dalam penelitian ini diperoleh dengan melakukan wawancara semistructured dan dilakukan dengan menggunakan instrumen penelitian berupa outline interview, sebagian informasi diperoleh dengan mengirimkan pertanyaan melalui fasilitas email. Adapun pengambilan data dilakukan dari masyarakat khususnya dari pegiat jender (anggota atau peng-rus APPHGI/ Asosiasi Pengajar dan Peminat Hukum Berperspektif Gender se-Indonesia, ketua Pusat Studi Gender) dan di luar APPHGI.

\footnotetext{
Trusto Subekti, "Interpretsi Hakim, Pengacara dan Notaris Terhadap Konsep Harta Bersama Menurut UU No. 1 Tahun 1974 Tentang Perkawinan di Kabupaten Banyumas (Studi Tentang Kriteria Yang Digunakan Dalam Mengkualifikasi Harta Bersama)", J urnal Dinamika Hukum, Vol. 12 No. 4 Mei 2008, Purwokerto: FH Unsoed, hlm. 102.
} 
Sementara metode analisis yang digunakan adalah analisis kualitatif khususnya feminis legal analysis.

\section{Pembahasan}

Pembahasan dalam penelitian ini dispesifikasi menjadi dua bagian yaitu hasil penelitian dan analisis untuk menjawab permasalahan dalam penelitian ini.

\section{Hasil Penelitian}

Hasil penelitian ini menunjukkan jawaban nara sumber terhadap daftar pertanyaan yang diajukan pada nara sumber dalam kaitannya dengan status kedudukan sebagai kepala keluarga dan hal-hal yang berkaitan dengan status tersebut. Meskipun pertanyaan-pertanyaan tersebut bersifat personal, tetapi itu penting karena jawaban-jawaban tersebut merefleksikan perilaku dan persepsi nara sumber dalam merespon permasalahan yang erat kaitannya dengan kedudukan sebagai kepala keluarga. Hal ini didasarkan pada argumen aliran feminis bahwa "personal is political" yang berarti bahwa setiap individu mampu membuat pertimbangan sendiri dan juga mampu membuat keputusan sendiri melalui prosedur tertentu, dan keputusannya itulah yang merupakan sikap politik mereka terhadap sesuatu hal. Sehingga setiap orang termasuk perempuan mempunyai kepercayaan sendiri terhadap aturan-aturan yang tidak selalu formal berdasarkan pengertian dan pemahaman yang mereka yakini terhadap nilai-nilai tertentu. Hasil yang diperoleh dari penelitian kesetaraan, hak dan kewajiban sebagai suami istri, hak dan kewajiban sebagai orang tua, hak kewajiban terhadap harta serta tentang pewarisan.

\section{Konsep kesetaraan dan kepemimpinan}

Nara sumber diminta memberikan jawaban mengenai konsep kesetaraan dan kepemimpinan dan hasilnya seperti terdapat dalam Figur 1. Figur tersebut menggambarkan empat hal yaitu persepsi konsep kesetaraan apakah identik dengan kesamaan atau perbedaan, alternatif kepemimpinan suami atau istri dalam rumah tangga, serta persepsi kepatuhan istri terhadap suami.

Pertama, persepsi makna kesetaraan dengan kesamaan. Hasil penelitian menunjukkan bahwa mayoritas nara sumber menyatakan kesetaraan dimaknai dengan perbedaan seperti terlihat pada Figur 1. Ini berarti untuk mencapai kesetaraan antara laki-laki dengan perempuan tidak berarti keduanya harus sama, hanya satu orang dari delapan nara sumber yang menjawab bahwa keduanya harus sama.

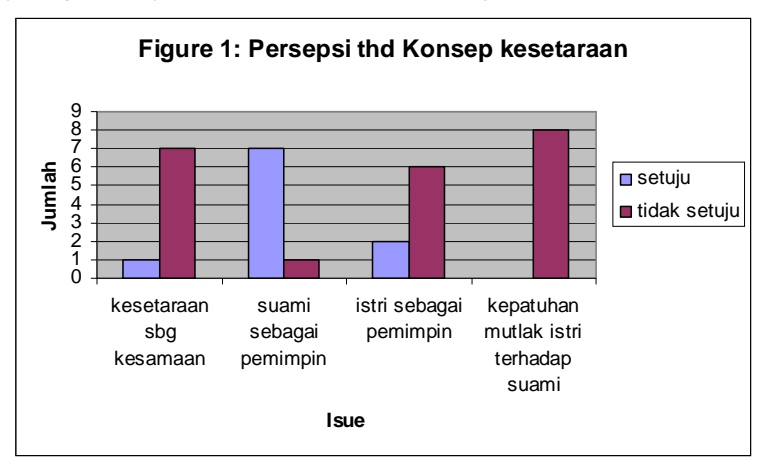

Sumber: Data Iapangan, 2009.

Sumber informasi yang tidak setuju kesetaraan diartikan dengan perbedaan karena beralasan bahwa semua berasal dari kodrat yang berbeda, seperti diungkapan oleh salah satu sumber informasi bahwa secara kodrati manusia memang diciptakan berbeda-beda dengan potensi yang berbeda-beda. Maka tidaklah adil jika keadaan yang berbeda tersebut harus menghasilkan outcome yang sama. Karena pemahaman terhadap perbedaan yang ada dan pemberian ruang pada perbedaan itu sangat diperlukan dalam membangun keluarga yang berkualitas dan mampu mencapai tujuannya.

Kedua, persepsi sifat kepemimpinan suami dalam rumah tangga. Sama dengan hasil tentang makna kesetaraan, mayoritas nara sumber menyetujui bahwa suami tetap sebagai pemimpin dalam keluarga. Sebagian besar mendasarkan pada keyakinan yang sudah dianutnya yang menyebutkan tentang hal ini. Hanya satu yang menyatakan bahwa kepemimpinan bisa dipertukarkan antara suami istri tergantung pada siapa yang lebih berkualitas diantara keduanya.

Ketiga, persepsi syarat-syarat yang harus dipunyai suami sebagai pemimpin rumah tang- 
ga. Saat ditanya tentang faktor yang melekat pada suami sehingga dia dijadikan pemimpin dalam rumah tangga terdapat jawaban yang bervariasi yang pada intinya dapat dikerucutkan menjadi jawaban sebagai berikut:

Nara sumber 1: "... suami bisa sebagai contoh, mampu memotivasi dan menyediakan nafkah yang cukup ..."

Nara sumber 2: "...mampu memberikan nafkah lahir dan batin..."

Nara sumber 3: "...Istri bisa menjadi pemimpim karena sifat-sifat kepemimpinan juga bisa dimiliki seorang istri. Akan tetapi perlu diingat bahwa masalah kepemimpinan bukan hanya sekedar penempatan siapa bawahan dan siapa atasan (menciptakan suasana yang hierarchical). Akan tetapi juga pada prinsip bahwa pemimpin adalah orang yang melayani dan menunjukkan jalan yang benar, dan mengajak orang-orang yang dipimpinnya melalui jalan itu. J adi tidak hanya dalam batas pandangan bahwa suami harus jadi pemimpin atau istri yang jadi pemimpin tetapi lebih pada bagaimana menciptakan keluarga yang dapat mendiskusikan aktifitas dan perjalan keluarga tersebut dengan baik..."

Keempat, persepsi istri sebagai pemimpin terhadap suaminya. Nara sumber yang menyetujui, bahwa istri dapat bertindak sebagai pemimpin dalam rumah tangga atau lebih cenderung tidak menghendaki adanya kepala dalam rumah tangga, hanya terdapat satu nara sumber, dengan mengatakan, “...mengubah stereotipe sehingga tidak ada kepala keluarga dalam rumah tangga...". Tetapi sebagian besar nara sumber ( 7 diantara 8 orang) berpendapat bahwa suami masih patut sebagai pemimpin bagi keluarganya termasuk istrinya.

Kelima, persepsi terhadap kepatuhan istri terhadap suaminya. Hasil penelitian yang didapat tentang kepatuhan mutlak istri terhadap suami menunjukkan bahwa semua nara sumber menjawab perlunya istri patuh terhadap suami. Akan tetapi mereka memberikan reservasi dengan menyatakan bahwa kepatuhan itu tidak bersifat mutlak, tetapi dibatasi beberapa alasan berikut, yaitu: untuk kebaikan, sesuai dengan tuntutan agama dan untuk ke- baikan, kalau yang dimintakan adalah hal-hal yang bertentangan dengan ajaran agama atau hukum negara yang akibatnya akan membahayakan istri atau anggota keluarga yang lain, atau bahkan menghancurkan keluarga itu, maka perintah suami tidak harus dituruti.

\section{Hak dan kewaj iban suami istri.}

Masalah persepsi terhadap hak dan kewajiban yang menjadi fokus penelitian ini terdiri dari beberapa hal yang meliputi perlunya seorang istri mempunyai penghasilan sendiri, penangungjawab penyedia nafkah (lahir), penanggungjawab urusan keluarga, kemungkinan dapat tidaknya suami istri digugat kalau mereka tidak melaksanakan kewajibannya. Adapun data dari penelitian mengenai persepsi hal-hal tersebut disajikan seperti terlihat pada Figure 2 dan 3 berikut.

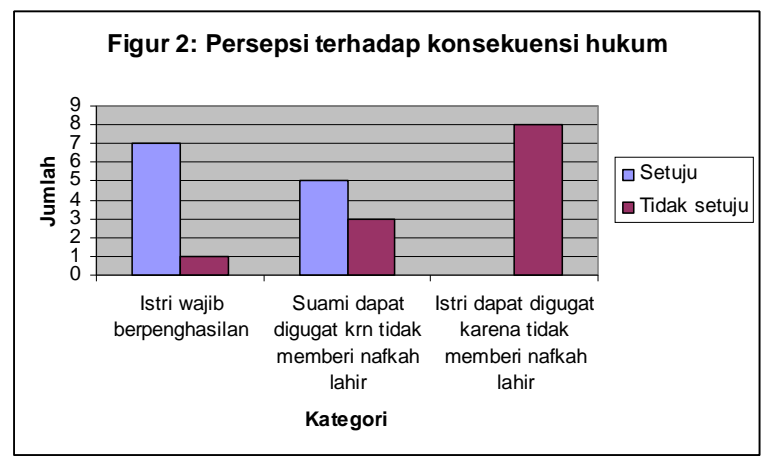

Sumber: Data Iapangan, 2009

Pertama, persepsi terhadap kewajiban perempuan untuk mencari nafkah. Hasil penelitian dalam Figur 2 menunjukkan bahwa mayoritas nara sumber menghendaki istri untuk mempunyai penghasilan sendiri. Dari delapan nara sumber, tujuh menjawab perlunya istri mempunyai kemandirian ekonomi. Beberapa alasan yang dikemukakan perlunya istri mempunyai penghasilan sendiri antara lain: agar lebih mudah menjalankan pemenuhan kebutuhan sehari-hari dan agar mempunyai kemampuan tawar yang besar lebih terhadap putusan suami

Kedua, persepsi terhadap kewajiban atas pemenuhan kebutuhan nafkah. Tanggungjawab tentang nafkah dan pengurusan rumah tangga dapat digambarkan dalan Figur 3 berikut. Seperti tercantum dalam ini bahwa kewajiban 
memberikan nafkah itu berada di pundak suami. Dari delapan nara sumber, lima menjawab laki-lakilah yang harus bertanggungjawab terhadap pemenuhan kebutuhan ekonomi sementara tiga yang lainnya menyatakan pemenuhan kebutuhan ekonomi harus ditanggung bersama-sama. Jika dibandingkan dengan stereotip pencari nafkah maka terlihat terjadi pergeseran nilai. Secara konvensional dan legal stereotipe perempuan tidak mempunyai tanggungjawab untuk mencari nafkah, maka dalam hasil penelitian ini 3 dari 8 nara sumber menyatakan bahwa perempuan bersama-sama dengan laki-laki juga punya kewajiban untuk memenuhi kebutuhan ekonomi. Data ini sedikit berbeda dengan hasil penelitian yang dilakukan Sendow seperti dikutip oleh Yulina dan Desrir Miftah yang menyatakan bahwa peranan perempuan dalam kagiatan usaha padi sawah adalah dominan dibandingkan pria. ${ }^{4}$

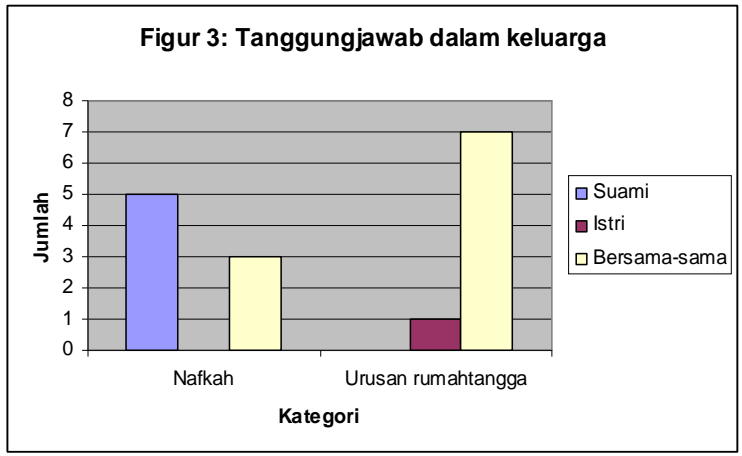

Sumber: Data Iapangan, 2009

Ketiga, persepsi terhadap kewajiban atas pekerjaan rumah dan apabila persepsi ini dihubungkan dengan kewajian suami dalam memenuhi kebutuhan ekonomi, maka data dalam Figur 3 juga menunjukkan bahwa suami istri bersama-sama bertanggungjawab terhadap pengurusan rumah tangga. Delapan dari nara sumber yang menyetujui kebersamaan tanggungjawab ini, hanya satu yang setuju istri bertanggungjawab urusan rumah tangga. Temuan ini adalah menggembirakan mengingat Pasal 34 (2) UU Perkawinan Nomor 1 tahun 1974 dimana istri wajib mengurus rumah tangga sebaikbaiknya.

Keempat, persepsi terhadap akibat hukum suami yang tidak memberi nafkah. Berkaitan dengan pertanyaan tentang kemungkinan dapat tidaknya suami digugat, karena tidak memenuhi kewajibannya memberi nafkah (lahir), maka diperoleh hasil bahwa sebagian besar sumber informsi menyatakan suami dapat digugat. Dari delapan jawaban, lima menyatakan bahwa suami dapat digugat kalau tidak memenuhi kebutuhan ekonomi sementara tiga lainnya lebih lunak pendapatnya. Lunaknya pendapat mereka itu terjadi karena alasan bahwa sebaiknya tidak terjadi gugat menggugat dan juga alasan istri bisa lebih mampu mengatasi kesulitan ekonomi karena kemampuannya dalam mencari nafkah.

Kelima, persepsi terhadap akibat hukum istri yang tidak memberi nafkah. Berbeda dengan dapat digugatnya suami karena melalaikan kewajibannya dalam memenuhi kebutuhan ekonomi, mayoritas sumber informasi menjawab bahwa istri tidak dapat digugat kalau tidak memberi nafkah pada keluarga. Mereka beralasan bahwa meskipun istri dapat berpartisipasi dalam memenuhi kebutuhan ekonomi bahkan dalam beberapa kasus istri sebagai tulang punggung keluarga, tetapi mereka tidak dapat digugat karena ketidakmampuan dalam sisi ini. Kalau sampai istri dapat digugat karena hal ini, maka ini berarti tidak hanya menambah beban ekonomi pada pundak istri, tetapi juga juga sekaligus menambah beban hukum pada pundak istri.

\section{Hak dan kewajiban sebagai orang tua}

Hasil penelitian tentang hak dan kewajiban orang tua dipaparkan dalam Figur 4 yang terdiri dari kewajiban ayah memberikan nafkah, kewajiban ibu memberikan nafkah pada keluarga, kewajiban mendidik anak serta kewajiban anak terhadap orang tua. 


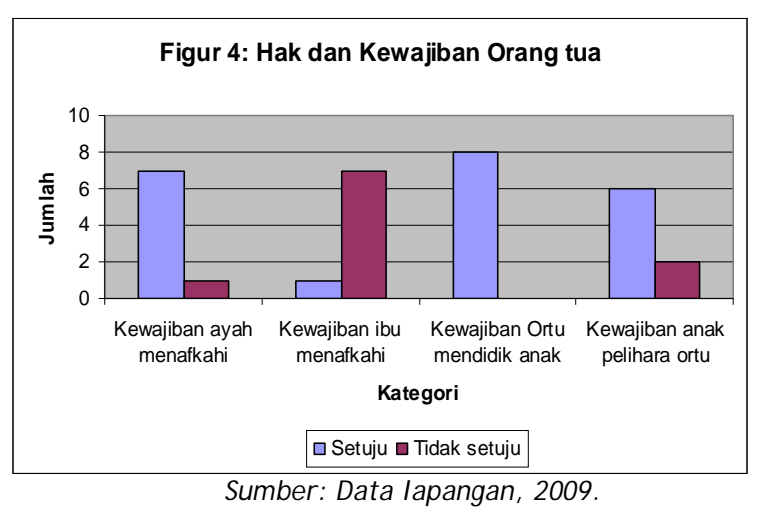

Pertama, persepsi terhadap kewajiban ayah memberi nafkah kepada anaknya. Senada dengan tanggungjawab ayah atas nafkah keluarga seperti yang tercantum dalam Figur 3, ternyata sebagian nara sumber setuju suami sebagai pencari dan pemenuhan nafkah utama. Dari Figure 4 terlihat bahwa delapan sumber informasi, tujuh nara sumber setuju ayah sebagai penanggungjawab utama dalam pemenuhan nafkah anaknya. Sebagian besar berpendapat karena memang itulah yang diperintahkan oleh agama. Sementara hanya satu yang menyatakan ketidaksetujuannya karena beralasan bahwa seharusnya suami istri bersamasama bertanggungjawab dalam pemenuhan kebutuhan ekonomi karena anak tersebut anak mereka berdua dan untuk alasan kesetaraan.

Kedua, persepsi terhadap kewajiban istri/ibu dalam memberi nafkah kepada anaknya. Data penelitian dalam Figur 4 menunjukkan bahwa sebagian besar berpendapat bahwa istri juga mempunyai kewajiban memberi nafkah terhadap anaknya. Dari delapan sumber informasi yang menyatakan setuju istri/ibu punya kewajiban sama dengan suami, hanya satu nara sumber yang menyatakan bahwa istri tidak wajib memberi nafkah kepada kepada keluarga. la berpendapat karena penghasilan istri itu hanya sebagai penghasilan tambahan. Sehingga data ini menunjukkan bergesernya peran ibu yang semula hanya dirumah ternyata partisipasinya dalam mencari nafkah merupakan alasan untuk keluar rumah.

Ketiga, persepsi terhadap kewajiban mendidik anak. Nara sumber, ketika ditanya tentang siapa yang bertanggungjawab terhadap pendidikan anak, terdapat suara yang bulat dari sumber informasi dimana kesembilan sumber informasi sebagai pegiat jender menyatakan bahwa suami istri bertanggungjawab bersama-sama terhadap pendidikan anak.

Keempat, persepsi terhadap kewajiban anak memenuhi kebutuhan orangtua. Nara sumber, ketika ditanya tentang kewajiban anak terhadap orang tua jika mereka sudah dewasa, terdapat temuan bahwa tidak semua setuju kewajiban anak untuk mensupport orang tua mereka. Dari delapan sumber informasi, enam menyatakan bahwa anak mempunyai kewajiban untuk mensupport orang tua mereka, sementara dua lainnya menyatakan bahwa support anak kepada orang tua mereka tidak merupakan kewajiban. Nara sumber yang setuju beralasan bahwa mereka perlu membalas budi kebaikan orang tua dan juga keinginan untuk membahagiakan orang tua terlepas apakah orang tua mereka mampu secara ekonomi atau tidak. J ikapun orang tua mereka mampu secara ekonomi, support pada orang tua tersebut tetap perlu karena itu merupakan ekspresi perhatian anak terhadap orang tua, yang diharapkan akan membawa kebahagiaan ataupun kebanggaan. Sementara yang tidak setuju perlunya anak memenuhi kebutuhan orang tua beralasan bahwa kewajiban tersebut hanya timbul manakala anak melihat orang tuanya tidak mampu secara ekonomi.

\section{Hak dan kewajiban terhadap harta}

Materi merupakan satu hal yang penting dalam membina trumah tangga. Relasi suami istri cenderung dipengaruhi keberadaan harta ini, bahkan seringkali merupakan salah satu sebab terjadinya perceraian. Untuk mengetahui salah satu akibat perkawinan menyangkut juga masalah keberadaan harta baik harta bawaan maupun harta asal. Hasil penelitain dalam Figur 5 menunjukkan hak dan kewajiban terhadap harta baik meliputi kewajiban suami istri terhadap harta bersama maupun terhadap harta bawaan. 


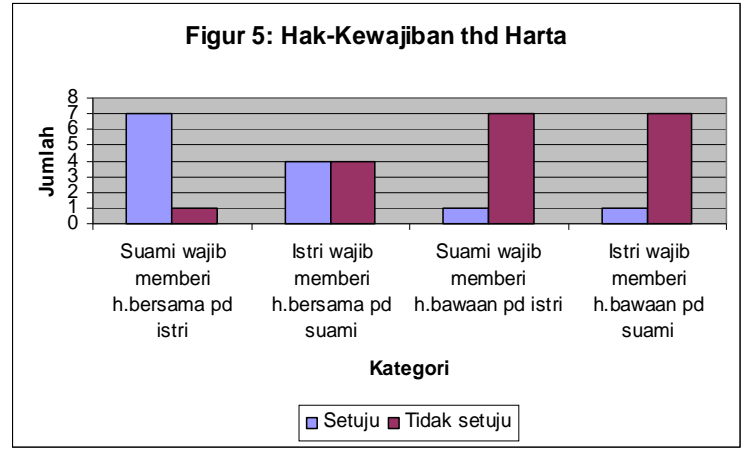

Sumber: Data Iapangan, 2009

Pertama, persepsi terhadap status harta bersama. Hasil penelitian dalam Figur 5 menunjukkan bahwa hampir semua suami harus memberikan harta bersama kepada istri (keluarga). Hal ini seiring dengan tanggung jawab suami untuk melakukan kewajibannya memenuhi kebutuhan rumah tangga dimana tujuh sumber informasi memberikan jawabannya yang sama. Tetapi hanya satu tidak setuju dengan alasan bahwa sebaiknya istri juga melakukan hal yang sama sehingga pemberian ini dilakukan bersama-sama untuk saling memberi.

Kedua, persepsi kewajiban istri memberikan harta bersama. Berdasar hasil penelitian, ternyata tidak seperti hasil pada kewajiban suami memberikan harta bersamanya kepada istri (keluarga), lebih sedikit nara sumber yang menyatakan bahwa harta bersama yang diperoleh istri tidak diwajibkan untuk diberikan kepada suami. Hal ini terlihat pada Figur 5 diamana hanya empat sumber informasi (setengah jumah nara sumber) setuju istri untuk memberikan harta bersama kepada suami. Hal ini ditengarai bahwa memang suami tidak membadap support istri secara langsung, tetapi jika dihubungkan dengan pertanyaan nomor 12 maka dapat disimpulkan bahwa istri mensupport keluarga lewat pemenuhan terhadap kebutuhan anak.

Ketiga, persepsi terhadap harta bawaan suami. Sebagian besar sumber informasi menyetujui suami tidak punya kewajiban untuk memberikan harta bawaan kepada istrinya. Terlihat pada Figur 5 bahwa dari tuj uh sumber informasi, hanya satu yang menyetujui untuk memberikan harta bawaan pada istri, itupun dengan melihat konteksnya. Dimana yang dimaksudkan konteks disini adalah fokus pada kebutuhan keluarga, bukan pada kebutuhan istri secara pribadi.

Keempat, persepsi terhadap harta bawaan istri. Persepsi ini Simetri dengan hasil persepsi kewajiban suami untuk tidak memberikan harta bawaaan kepada istri. Dari delapan orang dalam Figur 5, hanya satu sumber informasi yang menyatakan bahwa istri wajib memberikan harta bawaannya kepada suaminya dengan alasan bahwa sudah terjadi persatuan diantara keduanya, sehingga diperlukan pula persatuan harta bawaan karena lebih mendekati kesetaraan.

\section{Pewarisan}

Pertama, persepsi terhadap kesamaan pembagian warisan. Berkaitan dengan pewarisan diperoleh hasil bahwa terdapat perbandingan yang seimbang antara yang setuju dan yang menolak pembagian pewarisan perempuan setengah dari laki-laki seperti terlihat pada Figur 6. Figur tersebut menunjukkan bahwa sumber informasi yang setuju dan tidak setuju masing-masing berjumlah 4 orang. Meskipun jumlah mereka sebanding yang menarik adalah terdapat alasan yang berbeda-beda yang menyertainya. Nara sumber yang setuju berpendapat bahwa laki-laki memang pantas mendapatkan jumah pewarisan dua kali lipat dari perempuan karena besarnya tanggungjawab mereka terhadap ekonomi keluarga dimana akhirnya perempuan (istri) juga yang menikmati. Sementara alasan ketidaksetujuan perbedaan besarnya warisan dikarenakan kesetaraan dimana tidak diperlukan pembedaan jumlah besar warisan. Alasan lain yaitu perbedaan jumlah tidak diperlukan karena untuk memberikan kesan yang baik antara pewaris dan ahli waris seperti dikatakan salah satu sumber informasi bahwa, warisan secara hakikat sebetulnya merupakan kenang-kenangan bagi orang yang ditinggalkan. Maka sangatlah baik jika kenang-kenangan itu diberikan secara merata bagi laki-laki maupun perempuan. Agara mereka memperoleh kesan yang sama baiknya terhadap orang yang meninggalkan warisan itu. 


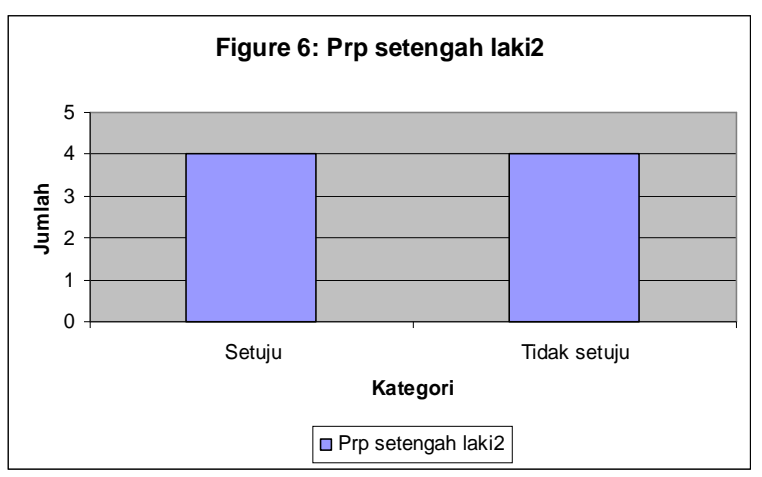

Sumber: Data Iapangan, 2009.

\section{Analisis}

\section{Analisis Yuridis Terhadap Relasi J ender dalam Keluarga}

Keluarga merupakan kesatuan terkecil dari masyarakat. Keluarga merupakan sokoguru dari masyarakat dimana pendidikan anggota masyarakat dimulai. Keberadaan keluarga yang sehat dan sejahtera dapat diharapkan adanya masyarakat yang sehat dan tertib. Di dalam hubungan kekeluargaan, moral, sopan santun dan agama memainkan peranan yang sangat mendalam. Menjunjung tinggi moral dan ketertiban umum merupakan kewajiban negara. Itulah sebabnya negara yang mengeluarkan banyak peraturan tentang hukum keluarga yang bersifat memaksa.

Subekti memberikan rumusan hukum keluarga kurang lebih sama tetapi lebih lengkap karena di dalamnya meliputi juga hubungan hukum dalam lapangan hukum harta kekayaan antara suami istri. Jadi hukum keluarga meliputi perkawinan dengan semua segi-seginya serta akibat yang timbul dari adanya perkawinan (peristiwa-peristiwa hukum yang hanya mungkin timbul karena adanya perkawinan) dan bahkan seringkali mengatur hubungan antara orang-orang dengan anak luar kawinnya yang tidak dapat dikatakan merupakan akibat suatu perkawinan. Uraian berikut menerangkan bagaimana kedudukan perempuan dalam hukum keluarga dikaitkan dengan hasil dalam penelitian ini.

\section{Konsep keseteraan dan kepemimpinan}

Pada dasarnya, sifat-sifat kepemimpinan juga bisa dimiliki seorang istri. Akan tetapi perlu diingat bahwa masalah kepemimpinan bukan hanya sekedar penempatan siapa bawahan dan siapa atasan (menciptakan suasana yang hierarchical). Akan tetapi juga pada prinsip bahwa pemimpin adalah orang yang melayani dan menunjukkan jalan yang benar, dan mengajak orang-orang yang dipimpinnya melalui jalan itu. Jadi tidak hanya dalam batas pandangan bahwa suami harus jadi pemimpin atau istri yang jadi pemimpin tetapi lebih pada bagaimana menciptakan keluarga yang dapat mendiskusikan aktifitas dan perjalan keluarga tersebut dengan baik.

Berdasar hasil penelitian dalam Figur 1 yang menunjukkan bahwa mayoritas pegiat jender memaknai kesetaraan dengan perbedaan. Hal ini diartikan bahwa untuk mencapai kesetaraan jender tidak berarti keduanya harus sama statusnya sebagai kepala keluarga. Bahkan kalau mereka dipaksakan sama statusnya dengan hak dan kewajiban yang sama, maka hal ini dapat dikatakan memaknai kesetaraan jender tetapi sampai pada taraf yang "kebablasan", dimana salah satu bukti adanya keraguan terhadap aktifitas perempuan untuk mengandung, melahirkan dan menyusui bukan sebagai kodrat tetapi sebagai seks. ${ }^{5}$ Mereka mengemukakan alasan bahwa suami dan istri berasal dari kodrat yang berbeda, seperti diungkapan oleh salah satu sumber informasi bahwa secara kodrati manusia memang diciptakan berbeda-beda dengan potensi yang berbeda-beda. Maka tidaklah adil jika keadaan yang berbeda tersebut harus menghasilkan outcome yang sama. Karena pemahaman terhadap perbedaan yang ada dan pemberian ruang pada perbedaan itu sangat diperlukan dalam membangun keluarga yang berkualitas dan mampu mencapai tujuannya.

Pola pikir ini apabila dihubungkan dengan pendapat Endang Sumiarni, maka kesetaraan yang diartikan dengan perbedaan dapat

Misiyah, "Pengalaman Perempuan: Sumber Pengetahuan Yang Membebaskan", J urnal Perempuan Vol. 48, J uli 2006, hlm. 40. 
dikategorikan pada Model kesetaraan yang substantive yang mengakui perbedaan antara laki-laki dan perempuan, dimana secara khusus mengakui bahwa fungsi reproduksi (misalnya mengandung) adalah fungsi khusus yang dipikul oleh perempuan dan merupakan fungsi sosial yang tidak dapat digunakan sebagai dasar untuk melakukan diskriminasi terhadap perempuan. Hal ini senada dengan dimaknainya perbedaan sebagai result-based management yang lebih memfokuskan pada "hasil" dimana kebijakan menerima "perbedaan proses" demi tercapainya kesamaan hasil.

Setiap kebijakan yang dikeluarkan harus memperhitungkan bias jender. Alasan perlunya konsep yang kedua ini karena perlakuan yang sama terhadap laki-laki dan perempuan tidak selalu membuahkan hasil yang positif bahkan tetap melanggengkan bias jender karena kondisi keterbelakangan yang dialami perempuan. Untuk itu kalau suatu kebijakan ingin memberikan hasil yang sama antara laki-laki dan perempuan, maka para pihak yang berkepentingan dalam pengambilan kebijakan harus mempunyai komitmen yang tinggi terhadap substantial equality (kesetaraan isi) dimana diperlukan kebijakan berbeda dalam "proses" antara lakilaki dan perempuan.

Delapan dari nara sumber pegiat jender, hanya satu orang yang menjawab bahwa keduanya harus sama. Hal ini didukung dengan argumentasinya bahwa untuk mencapai kesetaraan, maka kepemimpinan dimiliki bukan karena jenis kelaminnya tetapi karena atribut kelebihan yang dimilikinya, jadi siapapun yang memiliki kelebihan itu akan menjadi pemimpin tanpa memandang apakah ia berjenis kelamin laki-laki atau perempuan. Pemikiran ini biasanya banyak ditentang oleh ahli-ahli hukum yang berpikir dogmatis.

\section{Hak dan kewajiban suami istri}

Suami istri mempunyai kewajiban untuk menegakkan rumah tangga (Pasal 30 UU Perkawinan), 'Membina keluarga merupakan kewajiban/ tanggungjawab baik suami maupun istri bersama-sama'. Dalam keluarga suami berkedudukan sebagai kepala rumah tangga dan istri sebagai ibu rumah tangga (Pasal 31 ayat 3 UU Perkawinan). Berdasarkan hasil pada Figur 1, maka diperoleh kesimpulan bahwa suami dan istri mempunyai kedudukan seimbang dimana keseimbangan bukan berarti sama dimana dikatakan,' seimbang berarti tidak sama karena perbedaan kodrat laki-laki dan wanita berlainan sehingga tak mungkin kepada mereka diberikan hak dan kewajiban yang sama'. Konsekuensinya adalah bahwa suami istri harus saling menghormati, setia dan memberikan bantuan lahir maupun batin yang satu kepada yang lain (Pasal 33 UU Perkawinan, Pasal 103, 105 KUH Perdata), suami wajib melindungi istri dan memberikan segala keperluan hidup berumahtangga sesuai dengan kemampuannya dan istri wajib mengatur urusan rumah tangga sebaikbaiknya (Pasal 34 ayat 1 dan ayat 2 UU Perkawinan).

Berbeda dengan KUH Perdata dimana kedudukan suami sangat dominan seperti diatur dalam Pasal 105, "Setiap suami adalah kepala persatuan suami istri" dan Pasal 106 KUH Perdata menetapkan bahwa istri harus patuh kepada suami. Di dalam KUH Perdata juga ada ketentuan yang mengatakan bahwa suami istri harus tolong menolong dan saling membantu (Pasal 103) dan Pasal 107 ayat (2) mengatakan bahwa suami wajib melindungi dan memberi padanya segala apa yang perlu dan berpatut dengan kedudukan dan kemampuannya. Hanya saja ketidakmampuan suami ternyata merupakan salah satu faktor pendorong bagi seorang istri untuk mencari nafkah ${ }^{6}$.

Istri sepanjang perkawinan tetap wenang untuk bertindak (Pasal 31 ayat 2 UU Perkawinan). Disini terdapat perbedaan yang tajam dengan asas yang dianut dalam BW dimana pada asasnya seorang istri tidak wenang untuk melakukan tindakan-tindakan hukum dalam lapangan hukum kekayaan (Pasal 108, 110 dan 1330 BW). Namun dengan SEMA nomor 1115/ P/ 3292/ M/ 1963 tertanggal 4 Agustus 1964 ketentuan Pasal 108 dan 110 BW yang membatasi

\footnotetext{
Mariyah dan Tutik Priyantini, "Partisipasi Wanita Terhadap Keragaman Sumber Pendapatan Pekebun di Kabupaten Pasir", Jurnal EPP, Vol. 5 No. 2, 2008, hlm. 36.
} 
kewenangan bertindak seorang istri dinyatakan tidak berlaku lagi. Kewenangan bertindak ini menimbulkan suatu bentuk kekerasan tersendiri manakala karena suatu kondisi tertentu istri harus bekerja di luar rumah dan dia mengalami apa yang disebut dengan perdagangan orang atau ada yang malah menyebutnya dengan "kejahatan terorganisisr". ${ }^{7}$

\section{Hak atau kewajiban sebagai orang tua}

UU Nomor 1 tahun 1974 mengatur mengenai hubungan hukum yang lahir sebagai salah satu akibat adanya perkawinan mengenai susunan masyarakat di Indonesia dan pembinaan generasi berikutnya. Sebagai hubungan hukum yang berisi hak dan kewajiban antara orang tua dan anak ini merupakan hal yang harus ditunaikan. Pada asasnya seorang anak berada di bawah kekuasaan orang tuanya.

Anak adalah orang yang belum dewasa (Pasal 198 BW), sedang yang termasuk dalam kelompok orang yang belum dewasa menurut BW adalah mereka yang belum genap berusia 21 tahun dan tidak telah menikah sebelumnya (Pasal 330 BW). UU Perkawinan menganut asas yang lain yaitu anak yang berada di bawah kekuasaan orang tua adalah anak yang belum genap berusia 18 tahun dan belum menikah (Pasal 47 UU Perkawinan). Disini yang menjadi patokan adalah umur dan status tidak dipertimbangkan apakah anak tersebut sebelum mencapai usia yang disebutkan di atas telah mandiri atau belum mandiri dalam arti telah mempunyai penghasilan sendiri dan hidupnya tidak tergantung dari orang tuanya lagi.

Pihak yang menjalankan kekuasaan orang tua adalah ibu dan bapak si anak (Pasal 298 BW dan Pasal 45 ayat 1 UU Perkawinan). Kekuasaan di sini termasuk hak maupun kewajiban bagi orang tua. Kewajiban adalah untuk memelihara dan mendidik anak tersebut (Pasal 298 ayat 2 BW dan Pasal 45 ayat 1 UU Perkawinan). Prinsip kesamaan tanggungjawab ini bertentangan dengan stereotipe yang hidup dalam masyarakat

Kusumawardhani, "Pencegahan dan Penanggulangan Perdagangan Perempuan Yang Berorientasi Perlindungan Korban", J urnal Masyarakat dan Budaya, Vol. 12 No. 2, Tahun 2010, hlm. 333. bahwa kegagalan dalam mendidik anak dibebankan pada pundak seorang ibu. Hal ini senada dengan argumen yang dikemukakan seorang feminis religius, Amina Wadud, seperti dikutip oleh Yoke Sri Astuti yang menyatakan bahwa laki-laki disamping memenuhi kebutuhan materi juga harus bertanggungjawab mengasuh anak dan merawat keluarga. ${ }^{8}$ Selanjutnya Amina Wadud mengungkapkan bahwa suami istri hendaknya saling melengkapi tidak hanya dalam masalah keluarga tetapi juga dalam masalah kehidupan sosial kemasyarakatan.

Kewaj iban memelihara dan mendidik menurut UU Perkawinan berakhir pada waktu anak tersebut telah berdiri sendiri (Pasal 45 ayat 2 UU Perkawinan). Kata-kata berdiri sendiri berarti telah mempunyai penghasilan sendiri yang mencukupi untuk hidup tak bergantung dari orang tuanya.

Kekuasaan orang tua tersebut dilaksanakan oleh ayah sendiri (Pasal 300 ayat 1 BW). UU Perkawinan tidak secara tegas mengatakan demikian, namun demikian, dalam prakteknya memang yang menjalankan kekuasaan orang tua adalah ayahnya. Kecuali si ayah berhalangan atau dipecat/dibubarkan dari kekuasaan orang tua. Mereka pula yang dengan mengesampingkan orang lain mewakili si anak dalam segala tindakan hukum di dalam maupun diluar pengadilan. Adakalanya diperlukan suatu penyelenggaraan kepentingan seorang anak yang harus dilaksanakan melalui suatu tindakan hukum tertentu. Seorang anak pada prinsipnya tidak cakap untuk melakukan tindakan hukum, maka perlu adanya seseorang yang mewakilinya. Dalam hal ada orang tua yang menjalankan kekuasaan orang tualah yang mewakili si anak Dalam prakteknya yang mewakili adalah ayah anak yang bersangkutan. Dalam hal tidak hadirnya sang ayah, maka ibuk yang mewakilinya. Tetapi dengan perkembangan jaman dan dalam kasus ibu dianggap lebih cakap, maka ibulah yang mewakili anak tersebut, bahkan dalam kasus perceraianpun khususnya dalam perebutan hak asuh anak, maka anak tetap dilindungi dengan mempertimbangkan kepentingan ter-

8 Astuti, Y. S., "Qur'an Adil Bagi Perempuan?", Jurnal Perempuan, Vol. 48, Juli 2006, hlm. 139. 
baik bagi anak seperti diamanatkan dalam Pasal 2 UU Nomor 23 Tahun 2002 tentang Perlindungan Anak. Hanya saja definisi "kepentingan terbaik bagi anak" ini harus diputus oleh pengadilan, hal inilah yang menyebabkan kasus perebutan anak kadangkala menjadi berkepanjangan. ${ }^{9}$ Meskipun anak dilahirkan dalam keadaan suci, ternyata dalam praktek sosial yuridis, anak tidak mendapat perlindungan sepenuhnya, misalnhya dalam kasus anak yang lahir dari perkawinan sirri. ${ }^{10}$ Oleh karena itu Islamiyati menganjurkan dilakukannya penggalian tentang pencatatan perkawinan dalam hukum Islam secara eksplisit dengan tujuan untuk memberikan perlindungan pada anak khususnya dan perempuan umumnya.

Pada asasnya seorang anak yang telah dewasa mempunyai kewajiban untuk memelihara orang tua dan keluarganya dalam garis lurus keatas menurut kemampuannya apabila mereka memerlukannya. Imbalan atas pemeliharaan dan pendidikan orang tua terhadap anak, maka anak-anak yang sudah dewasa mempunyai kewajiban untuk merawat orang tua dan keluarga dalam garis lurus ke atas. Besarnya kewajiban pemeliharaan tidak ditentukan secara pasti, tetapi didasarkan atas kemampuan dan kebutuhan orang-orang yang bersangkutan (Pasal 46 ayat 2 UU Perkawinan dan Pasal 321 BW). Hal ini kalau dirunut merupakan timbal balik dari apa yang sudah diberikan orang tua walaupun tidak bisa disamakan.

\section{Hak dan Kewajiban Terhadap Harta Harta Bersama}

Pada asasnya harta benda yang diperoleh sepanjang perkawinan menjadi harta bersama (Pasal 35 ayat (1) dan Pasal 119 KUH Perdata). Maksud "sepanjang perkawinan" artinya sejak perkawinan dimulai hingga perkawinan ter-

9 Sudiman Sidabukke, "Perebutan Hak Asuh Anak Sebagai Wujud Pelanggaran Terhadap Hak-Hak Anak", Jurnal Dinamika Hak Asasi Manusia, Vol. 10 No. 3, September 2010, hlm. 218.

10 Islamiyati, "Pencatatan Pernikahan Sebagai Upaya Penanggulangan Nikah Sirri Dalam Hukum Islam (Analisis Terhadap Metode Penggalian Hukum)", J urnal MasalahMasalah Hukum, Vol. 39 No. 3, September 2010, hlm. 259. putus. Sedangkan harta bersama artinya harta tersebut milik suami dan istri bersama-sama. Dalam hal ini terdapat persamaan asas antara BW dan UUPerkawinan, tetapi kebersamaan harta di dalam BW bersifat menyeluruh artinya meliputi seluruh harta perkawinan yang sudah ada pada waktu penikahan dilangsungkan maupun yang diperoleh sepanjang perkawinan (Pasal 121 dan 122 BW), dan karenanya orang menyebutnya persatuan harta secara bulat, sedang dalam UU Perkawinan, persatuan harta tersebut hanya meliputi yang diperoleh sepanjang perkawinan saja (Pasal 35 UU Perkawinan).

Pengelolaan harta bersama, UU Perkawinan menentukan bahwa, suami atau istri dapat bertindak atas persetujuan kedua belah pihak. (Pasal 36 ayat (1) UU Perkawinan). Atas harta bersama suami atau istri dapat bertindak atas persetujuan bersama. Perhatikan kata "atau" bukan "dan", sehingga dapat disimpulkan bahwa istri sepanjang perkawinan tetap wenang untuk bertindak dalam lapangan hukum harta kekayaan. Sedangkan maksud kata "... atas persetujuan bersama" berarti bahwa istri tidak perlu didampingi suami tetapi cukup kalau ia menunjukkan adanya persetujuan suami, demikian juga sebaliknya.

BW menganut asas yang berlainan sekali. Atas harta persatuan suami sendirilah yang mengurusnya. Kepengurusan meliputi baik tindakan beheer maupun beschikking (Pasal 124 BW) dengan hanya sedikit pembatasan yaitu dalam hal ia memberikan hibah (Pasal 124 ayat (3) BW). Disini nampak betapa besarnya kekuasaan seorang suami atas harta persatuan. Sehingga Pasal 124 BW dapat ditafsirkan bahwa untuk kepengurusannya, suami tak usah bertanggungj awab terhadap siapapun.

\section{Harta pribadi}

Pada asasnya harta bawaan masingmasing suami dan istri seperti diatur dalam Pasal 35 ayat 2 UU Perkawinan, 'merupakan harta yang tetap dalam penguasaan masingmasing suami istri yang membawa kedalam perkawinan sepanjang para pihak tak menentukan lain'. Yang dimaksud dengan harta bawaan 
adalah harta yang dibawa masuk ke dalam suatu perkawinan. Jadi harta tersebut adalah harta yang sudah dimiliki suami atau istri pada saat mereka belum menikah. Maksud kata “...tetap dalam masing-masing penguasaan suami istri", artinya tetap menjadi milik pribadi suami atau istri yang bersangkutan. Dengan demikian harta pribadi terpisah dari harta bersama.

Arti kata-kata dalam Pasal 35 ayat 2 UU Perkawinan, "...sepanjang masing-masing (suami istri) tak menentukan lain" diartikan bahwa ketentuan tersebut merupakan ketentuan yang bersifat menambah/mengisi (aanvullend) dan karenanya para pihak dapat menyimpanginya dengan menentukan lain. Dengan demikian pada asasnya menurut UU Perkawinan harta yang dibawa pernikahan demi hukum terpisah dari harta bersama yang diperoleh sepanjang perkawinan. Harta tersebut tetap menjadi harta pribadi suami/istri yang membawanya kedalam perkawinan. Kedalam kelompok harta pribadi tersebut masih ditambah lagi harta hibah dan waris. Harta seperti itu sekalipun di dapat sepanjang perkawinan maka tetap menjadi harta suami istri yang memperolehnya dan tidak menjadi harta bersama, kecuali dalam perjanjian kawin telah ditentukan lain. (Pasal 35 ayat 2 jo. Pasal 20 UU Perkawinan), sehingga pada asasnya hukum harta perkawinan menurut BW menganut prinsip yang berbeda karena dalam perkawinan menurut BW hanya ada satu kelompok harta saja, kecuali para pihak menentukan lain, sehingga pada asasnya tidak ada harta pribadi. Harta pribadi pada asasnya baru ada kalau diperjanjikan atau ada penghibahan atau ada warisan oleh si penghibah/pewaris ditentukan tidak boleh masuk harta persatuan (Pasal 120 BW). J adi menurut BW pada asasnya hibah dan warisan masuk kedalam harta persatuan. Bahkan hasil dari harta pribadi masuk ke dalam harta persatuan seperti diatur dalam 146 BW yang mengatakan, "... dalam hal tak ada perjanjian mengenai hal itu segala hasil dan pendapatan harta kekayaan si istri adalah tersedia bagi suami".

Sementara pengelolaan harta bawaan, masing-masing suami dan istri mempunyai hak sepenuhnya untuk melakukan perbuatan hukum mengenai harta bendanya, seperti disarikan dari asas dalam Pasal 36 ayat 2 UU Perkawinan. Pada asasnya istri menurut UU Perkawinan tetap cakap untuk bertindak, maka suami atau istri masing-masing dapat mengambil tindakan beheer maupun beschikking atas harta bawaan masing-masing termasuk atas harta hibahan/ warisan. Dengan demikain dapat disimpulkan bahwa masing-masing istri dan suami mengelola hartanya sendiri. Adalah logis bahwa mereka tak perlu mempertanggungjawabkan pengelolaan mereka terhadap siapapun.

Berbeda sekali asas yang dianut dalam BW sebagai akibat dari ketidakcakapan istri dalam perkawinan dan demi agar di dalam satu rumah tangga tak terdapat lebih dari satu nahkoda, maka Pasal 105 ayat 3 BW menetapkan bahwa,'Setiap suami harus mengemudikan urusan harta kekayaan milik pribadi milik istrinya, kecuali kiranya tentang hal ini telah diperjanj ikan sebaliknya'. Tetapi atas kepengurusannya suami bertanggungjawab terhadap istri. (Pasal 105 ayat 4 BW).

\section{Pewarisan}

Hasil penelitian seperti terpaparkan dalam Figur 6 menunjukkan bahwa terdapat persepsi seimbang terhadap laki-laki yang mendapat warisan dua kali lipat dari perempuan. Meskipun menurut Ahmad Bangun Nasution, sistem pewarisan dalam praktik di Indonesia masih ada sistem yang berbeda perimbangannya seperti dalam sistem kebapaan (patriakhat) atau keibuan (matriakhat) ${ }^{11}$. Kelebihan laki-laki disini menurut Amina Wadud seperti dikutip oleh Ilyas Yunahar yang mengatakan bahwa keadilan akan dipenuhi manakala dipenuhi dua persyaratan, yaitu ${ }^{12}$ :

Pertama, apabila laki-laki punya atau sanggup membuktikan kelebihannya. Kelebihan disini maksudnya adalah kelebihan bagian

11 Nasution, A.B., "Penerapan Hukum Islam di Indonesia Sebelum Lahirnya UU Peradilan Agama (Analisis Penerapan Hukum Waris)", Jurnal Warta Dharmawangsa Vol. 21, 2009, hlm. 64.

12 Ilyas Yunahar, 1997, Feminisme dalam Kajian Tafsir AlQur'an Klasik dan Kontemporer, Yogyakarta: Pustaka Pelajar, hlm. 84. 
warisan sepanjang digunakan untuk mendukung perempuan. Perempuan disini bisa istrinya, ibunya mupun saudara perempuannya.

Kedua, apabila laki-laki mendukung perempuan dengan harta bendanya. Menurut Amina tidak secara otomatis setiap laki-laki memiliki kelebihan atas istrinya. Hal ini dikarenakan perempuan juga dapat mempunyai kelebihan dalam dua hal ini, maka kelebihan maknanya tidak berarti absolut sepanjang masa. Tetapi menurut Amina laki-laki tetap wajib memberikan jaminan materiil dan perlindungan karena tanggungjawab perempuan melahirkan anaknya, sehingga perempuan tidak perlu dibebani dengan tanggungjawab tambahan yang akan membahayakan tuntutan yang hanya ia sendiri bisa memenuhinya.

\section{Model Kepala Keluarga Berkesetaraan J ender}

Undang-Undang Nomor 14 Tahun 1970 mengenai Undang-Undang Pokok Perkawinan mengatur tentang perkawinan termasuk di dalamnya kedudukan suami istri dimana suami sebagai kepala keluarga dan istri ibu rumah tangga. Status ini menjadi hal yang dikritisi seiring dengan berkembangnya pergerakan feminisme. Apalagi dalam perkembangannya ada beberapa pihak yang menghendaki diubahnya status tersebut dimana tidak ada status kepala keluarga dalam rumah tangga ataupun kalau ada maka suami istri bersama-sama sebagai kepala keluarga. Artinya suami dan istri mempunyai hak dan kewajiban yang sama dalam menjalani kehidupan berumah tangga. Menurut pengusul perubahan status ini kehidupan akan lebih baik karena tercipta suatu kesamaan tersebut dan dapat dikatakan sudah tercapai kesetaraan dalam keluarga.

Berdasarkan kajian di lapangan nampak bahwa persoalan sangsi terhadap dilanggarnya peraturan yang diundangkan masih membayangi para pengusul tersebut. Hal ini terbukti dengan hasil penelitian bila dihubungkan dengan teori penerapan hukum dimana salah satu cirinya bahwa sangsi berlakunya hukum bersifat pemaksa. Dalam setiap perbuatan hukum yang dilakukan termasuk melakukan perkawinan pasti menimbulkan ikatan-ikatan hukum termasuk hak dan kewajiban yang pelaksanaannya kalau tidak dipenuhi akan dapat dipaksakan. Sifat pemaksaan ini juga mengikat bagi mereka yang tidak tahu dan atau tidak paham kalau peraturan sudah diundangkan karena terdapat adagium bahwa "setiap orang dianggap tahu akan Undang-undang"

Berdasarkan serangkaian proses dan hasil penelitian dihubungkan dengan studi pustaka yang telah dilakukan, maka model rumah tangga yang berkesetaraan jender yang dihasilkan dalam penelitian ini adalah mengharapkan lebih dipahaminya kesetaraan dalam keluarga dimana status suami sebagai kepala keluarga dan istri sebagai ibu rumah tangga seperti diatur dalam Pasal 31 ayat (3) UU Perkawinan diartikan mempunyai kesamaan dalam mewujudkan tujuan dari dilakukannya perkawinan tersebut. Hal ini dapat tercapai kalau diaplikasikan teori result-based management terhadap perbedaan status suami istri dalam rumah tangga. Sehingga status istri (perempuan) tanpa tanggungjawab menafkahi ekonomi jika suaminya ada dan tidak ada alasan khusus suami untuk mengelak dari tanggungjawab memenuhi ekonomi merupakan perlakuan khusus terhadap istri (preference) dan bukan merupakan diskriminasi terhadap suami. Sehingga tidaklah tepat mengartikan kesetaraan keluarga dengan mengaplikasikan teori treatment based management atau disebut dengan gender neutral policy dimana status suami disamakan dengan status istri sebagai kepala keluarga dalam rumah tangga. Hal ini dikarenakan pengaplikasian teori terakhir ini akan menyebabkan tambahan beban perempuan dari sisi ekonomi dan malah menciptakan aturan patriarki baru dalam perundang-undangan baru. Dengan demikian model relasi yang tepat dalam kesetaraan jender dalam keluarga menurut Sumarni adalah kesetaraan substantive, dimana status yang berbeda antara suami istri disatukan untuk mencapai tujuan yang sama melalui ikatan perkawinan yang mereka lakukan.

Kesetaraan substantif ini mematahkan argumen bahwa tanggungjawab istri dalam mengatur rumah tangga dibakukan perannya hanya pada ranah domestik saja, demikian juga suami 
hanya pada ranah publik. ${ }^{13}$ Keluarga sebagai institusi mandiri, memiliki otoritas dalam mengatur rumah tangganya, bahkan masing-masing pihak oleh UU PKDRT diberikan alternatif untuk mengekspresikan keinginannya. Pelarangan satu pihak terhadap pihak lain yang menginginkan hal berbeda akan dikonstruksikan melakukan suatu kekerasan. Suami yang memaksa istrinya bekerja contohnya akan dapat dituntut melakukan kekerasan terhadap rumah tangga. Demikian sebaliknya, kalau ingin melakukan pemberdayaan terhadap masyarakat, maka dapat dimulai dari perempuan itu sendiri dalam level keluarga. ${ }^{14}$

Sementara usulan untuk meniadakan adanya status kepala keluarga dalam rumah tangga secara hukum tidak bisa diterima karena status dalam rumah tangga lebih dilihat pada kewajiban yang melekat didalamnya dan konsekuensi hukum dari status tersebut. Oleh karena itu diseminasi dilanjutkan dengan sosialisasi terhadap pemahaman status kepala rumah tangga tersebut berserta tanggungjawab yang mengikutinya sangat membantu dalam mendapatkan ruang gerak untuk mendapatkan model keluarga yang lebih berkesetaraan jender. Keberhasilan usaha ini diharapkan lebih memberikan kesadaran sebagai kepala keluarga untuk memenuhi kewajibannya, karena pengingkaran hal ini akan menyulitkan perempuan atau istri itu sendiri. Bahkan penambahan atau perubahan status malah akan memberikan beban tambahan pada perempuan (istri) dimana istri diwajibakan secara hukum untuk memenuhi pemenuhan ekonomi sementara ada suami disampingnya. Dalam kondisi perempuan (istri) sebagai orang tua tunggal maka relasi ini lebih mudah dilakukan karena sesuai dengan hasil penelitian dalam Figure 2 dimana mayoritas narasumber menghendaki istri mempunyai penghasilan sendiri, maka istri (perempuan) tersebut tetap dapat memenuhi kewajiban rumah tangga dari sisi ekonomi. Walaupun suami istri

13 Tri Lisiani Prihatinah, "Tinjauan Filosofis UU Nimor 1 Tahun 1974", Jurnal Dinamika Hukum, Vol. 12 No. 4, Mei 2008, Purwokerto: FH Unsoed, hlm. 169.

14 Rusdiyah, "Gender Dan Hak Asasi Perempuan Dalam Islam", Jurnal Alhadharah, Vol. 2 No. 3, Januari 2003, hlm. 91. akan menghadapi masalah yang lebih besar untuk bisa survive di bidang ekonomi yaitu semakin ketatnya kompetisi dengan pihak luar di era global seperti ini. Hanya saja keterlibatan seorang ibu dalam produksi tidak selalu membawa akibat positif. Istri di Padang contohnya menghasilkan pendapatan, sementara Istri di Lamongan tidak demikian karena penghasilan istri dianggap merupakan penghasilan tambahan. ${ }^{15}$

\section{Penutup \\ Simpulan}

Hasil penelitian ini menunjukkan terjadinya persepsi yang bervariasi terhadap kedudukan suami istri bersama-sama sebagai kepala keluarga. Variasi tersebut seperti dipaparkan dalam ringkasan pembahasan dari hasil penelitian yang pada pokoknya adalah:

Pertama, mayoritas pegiat jender mengartikan kesetaraan dengan perbedaan; kedua, mayoritas pegiat jender setuju bahwa istri harus punya penghasilan sendiri; ketiga, mayoritas pegiat jender masih percaya bahwa suami sebagai pemimpin dan mempunyai kewajiban memenuhi nafkah kepada istri dan anaknya; keempat, mayoritas pegiat jender tidak setuju istri sebagai pemimpin dalam keluarga; kelima, Berbeda dengan suami yang dapat digugat kalau tidak memenuhi nafkah (lahir), maka semua pegiat jender tidak setuju istri dapat digugat kalau istri tersebut tidak dapat memenuhi nafkah (lahir). Hal ini berarti bahwa para pegiat jender masih menghendaki suami sebagai pemimpin keluarga, tetapi memberikan lebih banyak ruang pada istri untuk pergi keluar mencari penghasilan sendiri.

Berdasarkan hasil penelitian di atas, dapat dideskripsikan bahwa terdapat persepsi yang berbeda terhadap konsep model keberadaan suami istri bersama-sama sebagai kepala keluarga. Ini berarti hanya sebagian kecil yang menghendaki istri sebagai kepala keluarga. Mayoritas narasumber masih menghendaki sua-

\footnotetext{
15 Istiana, "Hikmah dan Mursidin, Optimalisasi Peran Gender Dalam Upaya Peningkatan Kesejahteraan Nelayan", J urnal Bijak dan Riset Sosek, Vol. 3 No. 2, 2008, hlm. 211.
} 
mi sebagai kepala keluarga, tetapi ini tidak berarti bahwa suami dapat melarang istrinya yang menghendaki berperan di ranah publik diantaranya mempunyai mata pencaharian sendiri. Pelarangan ini apabila dilakukan, maka akan melanggar UU PKDRT khususnya kekerasan ekonomi. Keterlibatan perempuan ini bukannya untuk menyamakan status, tetapi lebih dikarenakan alasan ekonomi sehingga istri mempunyai alasan tawar (bargaining power) kalau memang situasi menghendaki. Oleh karena itu, perempuan tidak perlu dibebani dengan tanggungjawab tambahan untuk mencari nafkah kecuali atas pilihannya sendiri. Dengan melihat perbedaan tanggungjawab antara laki-laki dan perempuan tersebut, maka tercipta ketergantungan sejajar atau seimbang dan saling menguntungkan antara laki-laki dan perempuan. Tetapi perlu diingat bahwa relasi jender dalam keluarga mempunyai beberapa dimensi yaitu dimensi materiil, dimensi spiritual, dan dimensi psikologis. Walaupun dimensi materiil merupakan hal penting terhadap relasi jender dalam keluarga, tetapi menempatkan dimensi ini sebagai satu-satunya alat ukuran dalam berkeluarga akan menjatuhkan pada perhitungan dagang semata.

\section{Saran}

Pada dasarnya mayoritas nara sumber masih tetap menghendaki suami sebagai kepala keluarga, oleh karena itu perlu dilakukan upaya pemahaman terhadap konsep kesetaraan sehingga bagi yang menghendaki istri sebagai kepala keluarga harus tahu konsekuensi hukumnya. Kedepannya status kepala keluarga ini menghadapi tantangan besar karena jangan sampai keinginan untuk mencapai kesetaraan tetapi malah menyebabkan beban tambahan kepada perempuan berupa kewajiban hukum untuk bertanggungj awab terhadap nafkah lahir (ekonomi).

Masukan-masukan yang tertuang dalam kesimpulan ini sangat penting manakala akan dilakukan perubahan terhadap peraturan perundangan khususnya Pasal 31 ayat (3) UU Perkawinan dimana diharapkan akan dapat memberi masukan yang berarti. Sehingga produk peraturan yang diundangkan bersifat responsif dapat terlaksana dengan baik, bukan malah sebaliknya yang membuat peraturan yang tidak sesuai dengan nilai-nilai yang masih diyakini oleh masyarakat.

\section{Daftar Pustaka}

Astuti, YS. "Qur'an Adil Bagi Perempuan?". J urnal Perempuan. Vol. 48. Juli 2006;

Islamiyati. "Pencatatan Pernikahan Sebagai Upaya Penanggulangan Nikah Sirri Dalam Hukum Islam (Analisis Terhadap Metode Penggalian Hukum)". Jurnal MasalahMasalah Hukum, Vol. 39 No. 3. September 2010 ;

Istiana. "Hikmah dan Mursidin, Optimalisasi Peran Gender Dalam Upaya Peningkatan Kesejahteraan Nelayan". J urnal Bijak dan Riset Sosek. Vol. 3 No. 2. Tahun 2008;

Kusumawardhani. "Pencegahan dan Penanggulangan Perdagangan Perempuan Yang Berorientasi Perlindungan Korban". Jurnal Masyarakat dan Budaya. Vol. 12 No. 2. Tahun 2010;

LBH-APIK/ Lembaga Bantuan Hukum-APIK. 2005. Usulan Amandemen UU Perkawinan No. 1 tahun 1974 berikut argumen-argumennya. J akarta: LBH APIK ;

Mariyah dan Tutik Priyantini. "Partisipasi Wanita Terhadap Keragaman Sumber Pendapatan Pekebun di Kabupaten Pasir". J urnal EPP. Vol. 5 No. 2. Tahun 2008;

Misiyah. "Pengalaman Perempuan: Sumber Pengetahuan yang Membebaskan". Jurnal Perempuan Vol. 48. J uli 2006;

Nasution, AB. "Penerapan Hukum Islam di Indonesia Sebelum Lahirnya UU Peradilan Agama (Analisis Penerapan Hukum Waris)". J urnal Warta Dharmawangsa. Vol. 21. Tahun 2009;

Prihatinah, Tri Lisiani. "Tinjauan Filosofis UU Nimor 1 Tahun 1974". J urnal Dinamika Hukum. Vol. 12 No. 4. Mei 2008. Purwokerto: FH Unsoed;

Rusdiyah. "Gender Dan Hak Asasi Perempuan Dalam Islam". J urnal Alhadharah. Vol. 2 No. 3. J anuari 2003;

Sidabukke, Sudiman. "Perebutan Hak Asuh Anak Sebagai Wujud Pelanggaran Terhadap Hak-Hak Anak", Jurnal Dinamika Hak 
Asasi Manusia. Vol. 10 No. 3. September 2010;

Subekti, Trusto. “Interpretsi Hakim, Pengacara dan Notaris Terhadap Konsep Harta Bersama Menurut UU No.1 Tahun 1974 Tentang Perkawinan di Kabupaten Banyumas (Studi Tentang Kriteria Yang Digunakan Dalam Mengkualifikasi Harta Bersama)". J urnal Dinamika Hukum, Vol. 12 No.4. Mei 2008. Purwokerto: FH Unsoed;
Sumiarni, Endang. 2005. Kajian Hukum Perkawinan Yang Berkesetaraan Jender. Yogyakarta: Wonderful Publishing Company.

Yulina dan Desrir Miftah. "Peranan Perempuan Dalam Pemberdayaan Ekonomi Keluarga". Jurnal Marwah. Vol. 8 No. 2. Desember 2009

Yunahar, Ilyas. 1997. Feminisme dalam Kajian Tafsir Al-Qur'an Klasik dan Kontemporer. Yogyakarta: Pustaka Pelajar 